\title{
Development of a System Dynamics Model for Evaluation of the Impact of Integration of Renewable Energy Sources on the Operational Efficiency of Energy Supply Facilities: Theoretical Background
}

\author{
Māris Balodis ${ }^{1}$, Valērijs Skribans ${ }^{2}$, Polina Ivanova ${ }^{3}$ \\ ${ }^{1-3}$ Riga Technical University
}

\begin{abstract}
Nowadays, energy companies operate in a highly competitive environment. To maintain the leader position, as a reaction to various changes energy companies must take appropriate steps in a timely manner.

Correct assessment of the situation ensures implementation of adequate measures. The situation can be assessed correctly by using a complex approach and/or analysing it according to the specific circumstances. The complex approach also envisages designing of an appropriate model, which studies the impact of changes on the research object, while dealing with the object within a system and as part of the system.

The article gives a theoretical background of the system dynamics model in order to evaluate the impact of integration of renewable energy sources (RES) on the operational efficiency of energy supply facilities (power and heat supply) on the national and regional levels, as well as provides the first modelling results.
\end{abstract}

Keywords - Efficiency, heat supply, power supply, renewable energy sources, research object, system dynamics model.

\section{INTRODUCTION}

The most topical issues for the promotion of the Latvian national economy are those related to the energy sector. These processes are characterised by increasing energy consumption, stricter environmental impact requirements, and more rapid price dynamics of the primary energy resources. These issues have emerged in many countries, but each of them has its own energy production and usage specifics.

The present situation in the Latvian energy sector can be described as follows (Zigurs et al., 2015):

- Increased competition among energy companies due to the expansion of the regional markets (new transmission connections);

- Significant changes in fuel and electricity market prices;

- Increased requirements for energy efficiency and the use of renewable energy sources;

- New regulatory mechanisms in the markets.

By responding correctly to the impact factors, it is possible for a specific operator to achieve bigger gains and ensure optimal development of the energy supply system in the long term. Prior to the implementation of fundamental measures affecting the energy systems, the situation must be evaluated by conducting a comprehensive analysis or applying a complex approach.

The situation analysis envisages focussing on a certain problem (situation) directly affecting only the research object within the given context.

In the event of the complex approach, the situation (problem) is being evaluated within a unified system.
While conducting the research, a system is developed where one of its elements is the research object, which is closely related to the other elements of the system on the national and regional levels. To examine the situation, its system dynamics model is designed using appropriate software tools for the calculations. The model comprises all the essential elements (blocks, sub-blocks, specific variables, parameters, etc.) and the most significant relations/links (direct, indirect, causal, feedback, etc.) that may affect the result.

In this article, the authors examine the impact of integration of RES on the operational efficiency of energy supply facilities by using both methods. Two Latvenergo JSC thermal power plants have been selected as the research object: Riga CHP-1 and Riga CHP-2. Both power plants are among the most advanced combined cycle power plants in Europe (reconstruction of Riga CHP-1 was completed in 2005 and of Riga CHP-2 in 2013). The power plants operate in a competitive environment in the region.

Until 2008, heat energy to the right bank heat networks of Riga City was mainly supplied by Latvenergo JSC thermal power plants. In recent years, heat source construction projects focusing on redistribution of the heat load used for co-generation have been appearing more and more frequently. The first such project was implemented in 2008 by the limited liability company Juglas Jauda, which built a natural gas internal combustion co-generation power plant in Riga CHP supply area. At present, the electrical power of this plant is $14.9 \mathrm{MW}_{\mathrm{el}}$, and its thermal power is $16 \mathrm{MW}_{\mathrm{th}}$. An increase in the share of the RES in power generation would reduce the load of Riga heat and power generation plants even more sharply (Kunickis et al., 2014).

\section{Key Concepts and Definitions}

By using the complex approach, the research object is dealt with within a system, which is a set of certain elements linked by a common purpose and close ties with one another. The system is built in compliance with the situation being examined and the purpose set for the development and application of the model. If the system is viewed in dynamics, the parameters change over time, and are relatively constant if viewed statically.

With the help of the system dynamics model, the system's behaviour is analysed over time depending on the structure of its elements and their mutual influence, including cause-effect relationships, feedbacks, exposure response rate, etc. By using mathematical equations of the interdependencies, calculation algorithms and special simulation modelling software, system 
dynamics models examine the set of interdependencies affecting the research object (Skribams, 2008; Hollmann \& Voss, 2005) System dynamics models analytically reflect the performance results of the established relationships when parameter values and statistical interdependencies of the indicators change in the dynamics. Answers are given to questions regarding what the development should be like taking into account changes in interdependencies (Skribans, 2009).

Normally, the system consists of material and non-material components. The material components are physical objects. The non-material components are social processes, relationships and their interaction, information flows, etc. (Blumberga, 2010).

For the system to operate optimally, all the elements (components, sub-systems, links, etc.) must be effectively integrated into the structure. On the other hand, operation of the elements depends on the operation of the overall system. All the elements have a certain purpose and sequence of inclusion into the overall system. While operating independently and flexibly, the system tends to maintain stability by applying corrections and by fluctuating. Correlations exist within the system itself and/or between external systems and their elements. The more complicated the system, the bigger potential it has for flexibility. However, coordination of too many system elements and links is complicated and leaves room for errors (Blumberga, 2010).

When developing a system dynamics model, it is important to determine all the main system elements, links and parameters directly affecting the researched situation (object), since the model's behaviour is determined by its structure. The designed system dynamics model is based on theoretical, mathematical and logical assumptions, as well as admissible simplifications of the actual situation (Hollmann \& Voss, 2005; Skribans \& Pocs, 2012).

\section{Justification of the Selected Modelling Method}

It is necessary to create the common system dynamics model of the energy sector. It will give a possibility to evaluate both the energy consumption trends and the factors directly influencing them as well as the sectoral changes. Such a model will take into account the potential improvement of the efficiency and the versatile feedbacks.

Forecasts of the energy sector in Latvia are most frequently made by using algorithmic and time series forecasting or trend methods. Basically, these methods take into account only the historical trends, which may change in the future. Consequently, these methods are mainly suitable for short-term forecasting of the sector (up to one and a half years) (Skribans, 2010).

Regression methods have a better quality and a slightly longer forecasting period. Regression methods make forecasts based on realistic influencing factors and use statistical information to determine the relationships. These interrelations may change in the course of time or due to external impacts, which are difficult to reflect in regression methods (Skribans, 2010).

By using the system dynamics method, it is possible to evaluate the cause-effect interrelations, including reciprocal interdependencies, which have a lasting nature and adapt the system's behaviour to external changes.
The system dynamics model includes interdependencies represented by non-linear differential equations (Herbst et al., 2012).

\section{Model Structure}

Since the reciprocal links of the energy sector are extensive and versatile, the system dynamics model of the Latvian energy sector consists of several sub-models (blocks) (see Fig. 1). The model blocks are divided into three groups: resources, production and consumption. A separate place is allocated to HPP (hydro-power plants), net electricity imports and similar forms of energy production. The resources block is constituted by the main blocks of primary energy resources. The primary energy resources are converted into other forms of energy, i.e., heat or electricity. Those are shown in the production blocks. Both the primary and produced energy (and energy generated by HPPs) are passed on to final customers that make up consumer unit blocks. They consist of transport, agriculture, households and other (industry and service sectors) blocks. The distribution pattern of the above-mentioned blocks is based on the specific character of the Latvian energy sector.

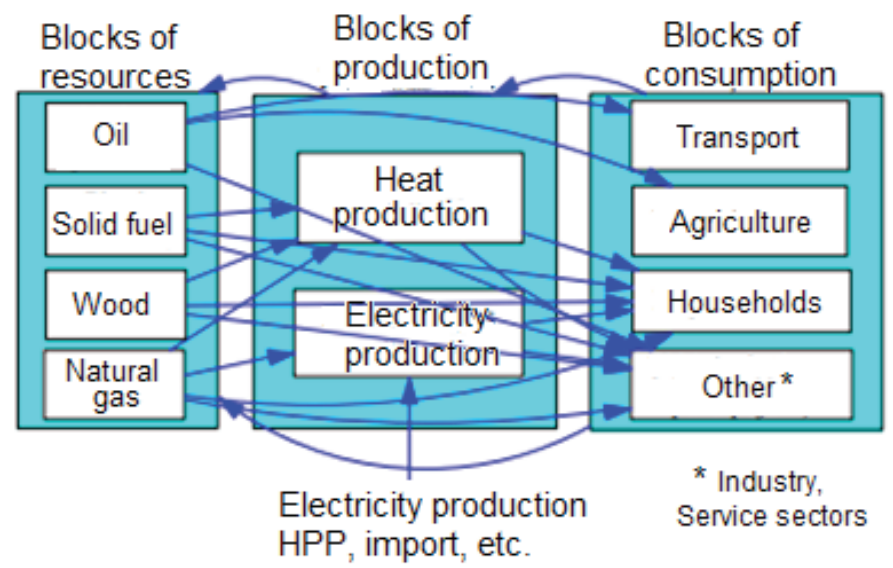

Fig. 1. General scheme of the Latvian energy sector system dynamics model (Skribans, 2010).

The size of the model depends on several factors: its intended application, availability of data, model development experience, the choice and use of software tools, etc. A model structure is considered flexible if it can be easily supplemented with new elements. The model can be simplified by replacing the mathematical operations with external exogenous indicators in compliance with modelling requirements (Ozolina \& Pocs, 2013).

Figure 1 shows the general scheme of the system dynamics model. A model structure was designed prior to the development of the system dynamics model for evaluation of the impact of renewable sources of energy on the efficiency of the energy supply (see Fig. 2). The research deals with the impact of integration of RES into energy production on the research object, which has been assumed as the basic element of the system. The selected research object is Latvenergo JSC thermal power plants, and the selected research system is the Latvian heat and power supply systems. The model is not going to reflect the RES influence on grids. 
The structure of the designed system dynamics model (see Fig. 2) reflects the general idea of the model and the main interrelationships, including also in the dynamics. For practical application, the model needs to be supplemented with several sub-elements. The "Research object" model block and the "Small CHPs" sub-block, for example, are represented by one element. They need to be "evolved" into a whole sub-system (see Figs. 3 and 4). The sub-models comprise system dynamics elements: storage, physical (material) flows, non-material and information flows, flow regulators and convectors (see Table I).
TABLE I

System Dynamics Elements [5]

\begin{tabular}{|c|c|l|}
\hline No. & Symbol & \multicolumn{1}{c|}{ Explanation } \\
\hline 1. & $=$ & Physical flow \\
\hline 2. & $\longrightarrow$ & Non-material and information flow \\
\hline 3. & $<\mathrm{C}>$ & $\begin{array}{l}\text { Convector or container "C" from the connected } \\
\text { sub-model }\end{array}$ \\
\hline 4. & 8 & Regulator of physical flow \\
\hline 6. & $\square$ & External environment \\
\hline 7. & & Storage "A" \\
\hline 8. & $\mathrm{~B}$ & Converter "B" \\
\hline
\end{tabular}
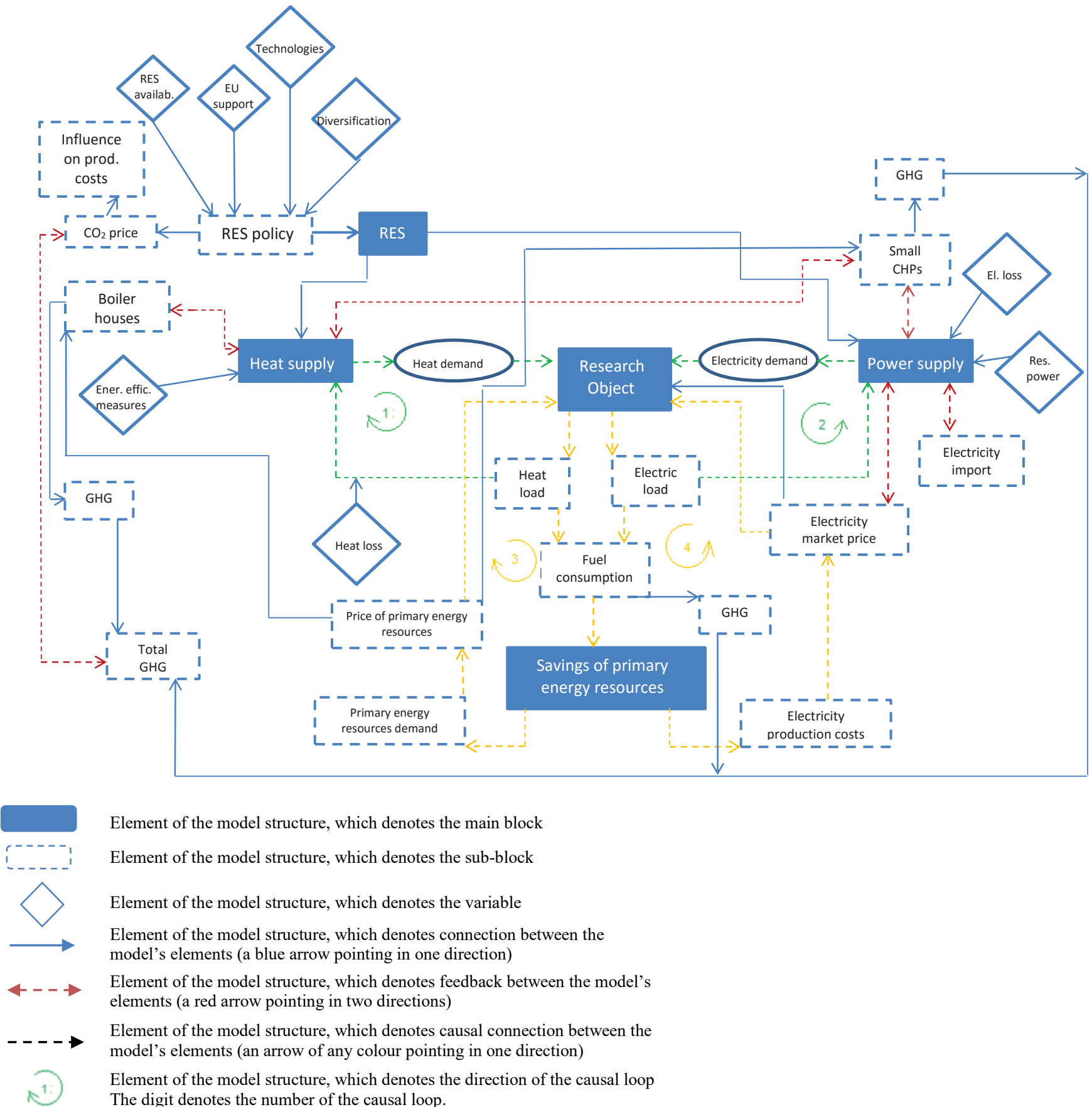

Element of the model structure, which denotes the main block

Element of the model structure, which denotes the sub-block

Element of the model structure, which denotes the variable

Element of the model structure, which denotes connection between the model's elements (a blue arrow pointing in one direction)

Element of the model structure, which denotes feedback between the model's elements (a red arrow pointing in two directions)

Element of the model structure, which denotes causal connection between the model's elements (an arrow of any colour pointing in one direction)

Element of the model structure, which denotes the direction of the causal loop The digit denotes the number of the causal loop.

Fig. 2. Structure of the system dynamics model for evaluation of the impact of integration of RES on the operational efficiency of energy supply facilities. 


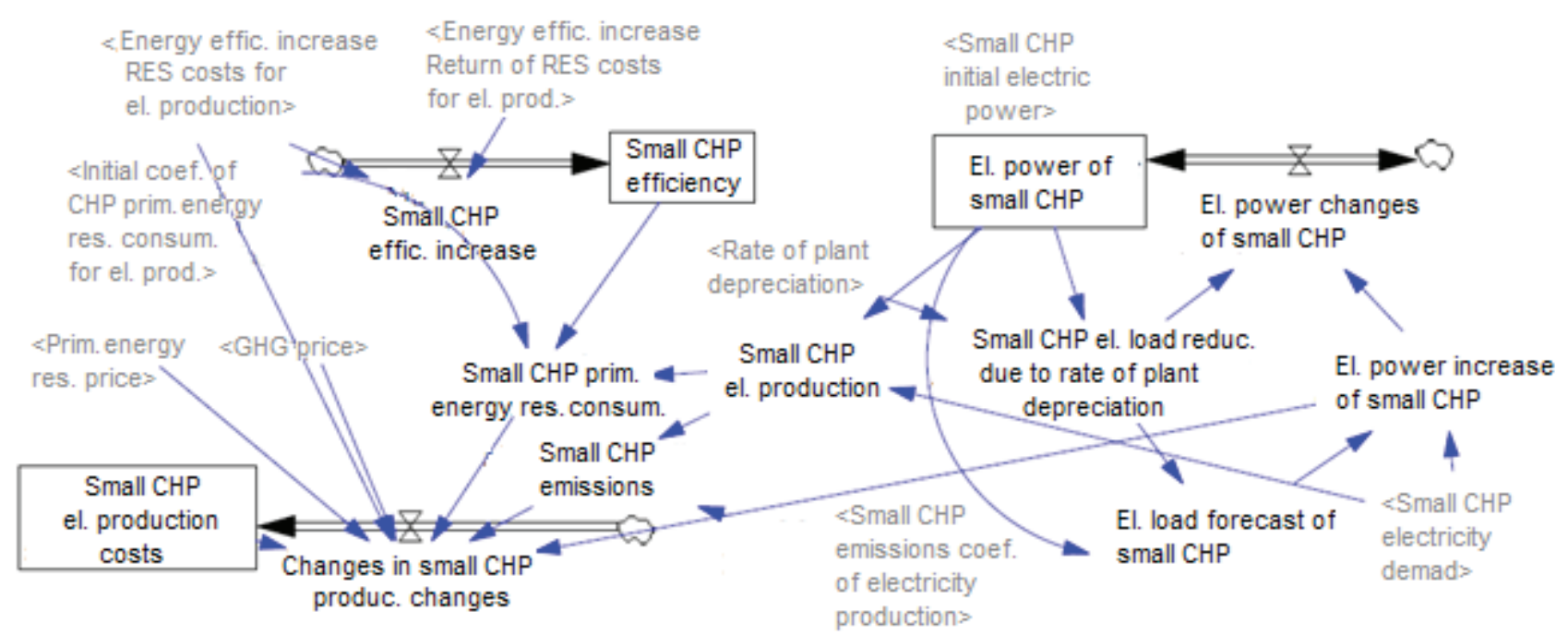

Fig. 3. An example of the system dynamics model: Sub-model of the "Small CHPs" sub-block.

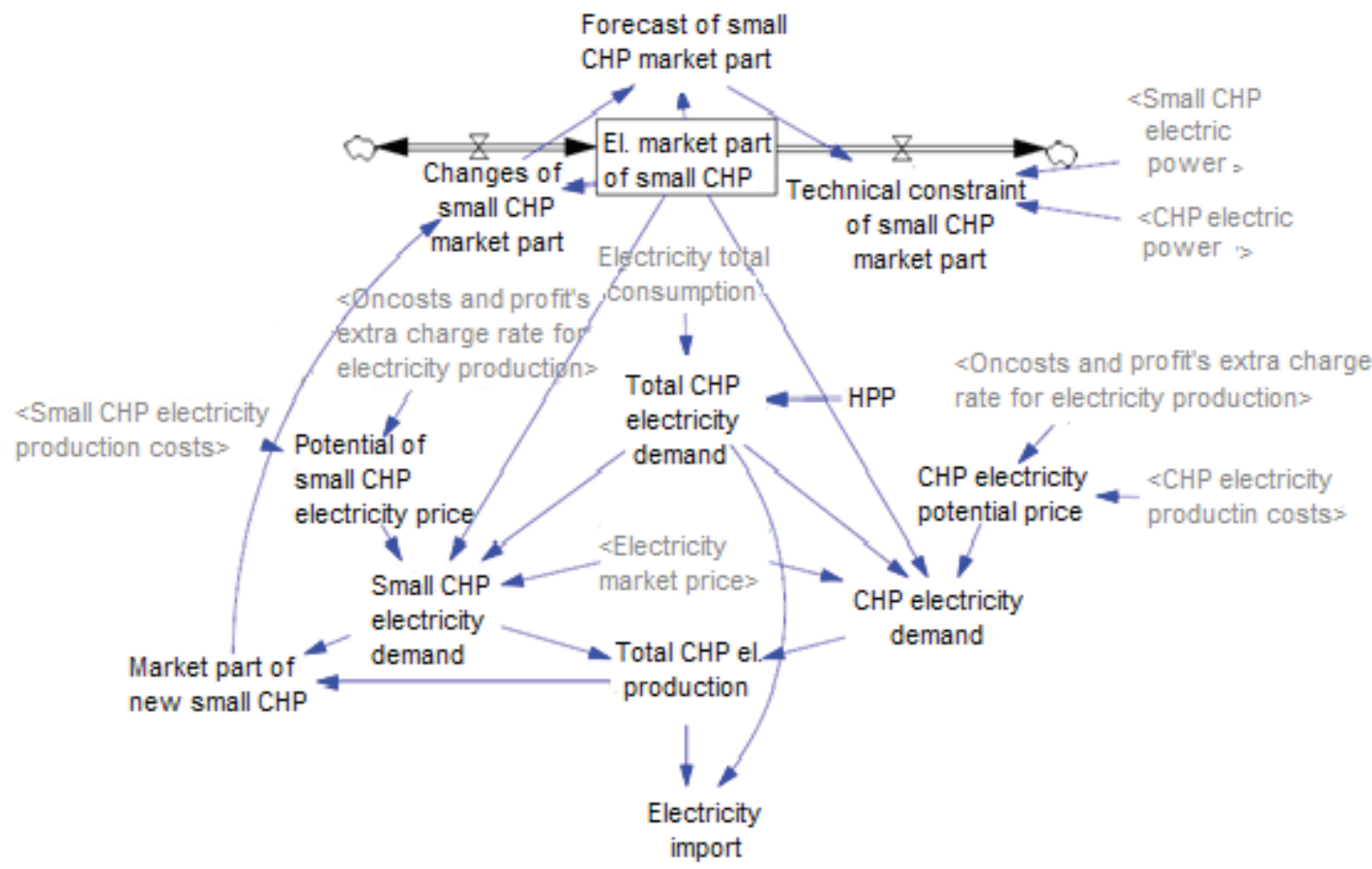

Fig. 4. An example of the system dynamics model: The "Research object" (Latvenergo JSC) sub-block.

\section{Development of the Model Algorithm}

A model prototype (see Fig. 5) showing the main blocks and links of the model was designed to develop an algorithm for the model. The model prototype or basic structure is made up of five main blocks:

- Block (1) - Renewable energy sources (RES);

- Block (2) - District heating;

- Block (3) - Power supply;

- Block (4) - Research object;

- Block (5) - Savings of primary energy resources.

The main blocks are closely interlinked. The main links among them are formed in the model.

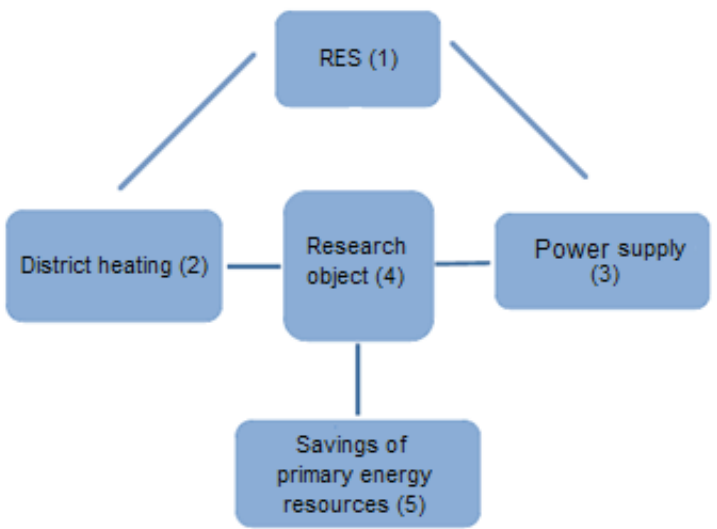

Fig. 5. Model prototype. 
Development of the model prototype can be characterised as application of the complex approach. First, the researched problem is being defined on a large scale. In other words, no one specific case is being determined related to a wider use of RES in the production of energy.

Second, the impact of RES integration on the research object is examined in a complex system constituted by the Latvian heat and power supply.

\section{A. Model Prototype RES Block (1)}

The RES block lists the potential renewable energy sources that can be used for energy production in Latvia. A distinction is made between the resources that can be used for thermal energy production (biomass, biogas, sun) and electricity generation (biofuels, biomass, biogas, water, wind, sun) (see Fig. 2).

The model assumes that integration of the renewable energy sources in the energy supply system depends on the implementation of the RES policy (RES policy sub-block). RES policy is also influenced by several variables. According to the designed model, these are: availability of renewable sources, availability of technologies, the European Union (EU) legislation, diversification of resources. The model takes into account that the $\mathrm{CO}_{2}$ allowance prices are affected by the RES policy being implemented, which in turn influences the production costs (see Figs. 2 and 3).

\section{B. Model Prototype Blocks: District Heating (2) and Power Supply (3)}

According to the designed model, integration of RES into the energy supply system affects both blocks: District heating and Power supply (see Fig. 2). The District heating block determines the heat energy demanded, while the Electricity supply blockthe electricity demanded. Several situations are being considered, for example, whether RES provides for introduction of new renewable energy sources into the system or diversification of the existing ones, which primarily meet the demand for heat energy and electricity beyond market competition. The rest of the energy demand would be covered by conventional sources of energy.

The District heating block is also directly affected by the Gas boiler houses sub-block and the variable Energy efficiency measures. A feedback is being formed between the Gas boiler houses sub-block and the District heating block (see Fig. 2).

Compared to the Heat supply block, the Power supply block has more sub-blocks and variables: the Electricity import and Small CHPs sub-blocks, and variables Reserved power and Electricity loss (see Fig. 2).

\section{Model Prototype Block: Research Object (4)}

As already mentioned, Latvenergo JSC thermal power plants Riga CHP-1 and Riga CHP-2 have been selected as the research object. The Research object block is divided into four parts: CHP-1 (co-generation power units), CHP-2 (co-generation power units), water boilers in the territory of CHP-1 and CHP-2, which in turn form a selection matrix.

This matrix provides for a variety of operating modes of heat and power generation plants depending on the assigned thermal and electrical load, as well as taking into account the influence of such sub-blocks as Price of primary energy resources, which also influence the Gas boiler houses and Small CHPs sub-blocks, and the Electricity market price block, influencing the Electricity supply block and forming with it a feedback. The research object ensures heat energy and electricity, influencing the Heat supply and Electricity supply blocks, respectively. As a result, two causal loops are formed (see Fig. 2), which are merged into a single loop and shown in Fig. 6.

Causal loop (1): any changes in the heat supply determine the heat load assigned to the research object, which in turn determines the operating modes of the research object and the selection of the equipment. The amount of heat energy produced by the research object, in turn, affects the overall district heating. The variable Heat loss affects the primary causal loop (see Figs. 2 and 6).

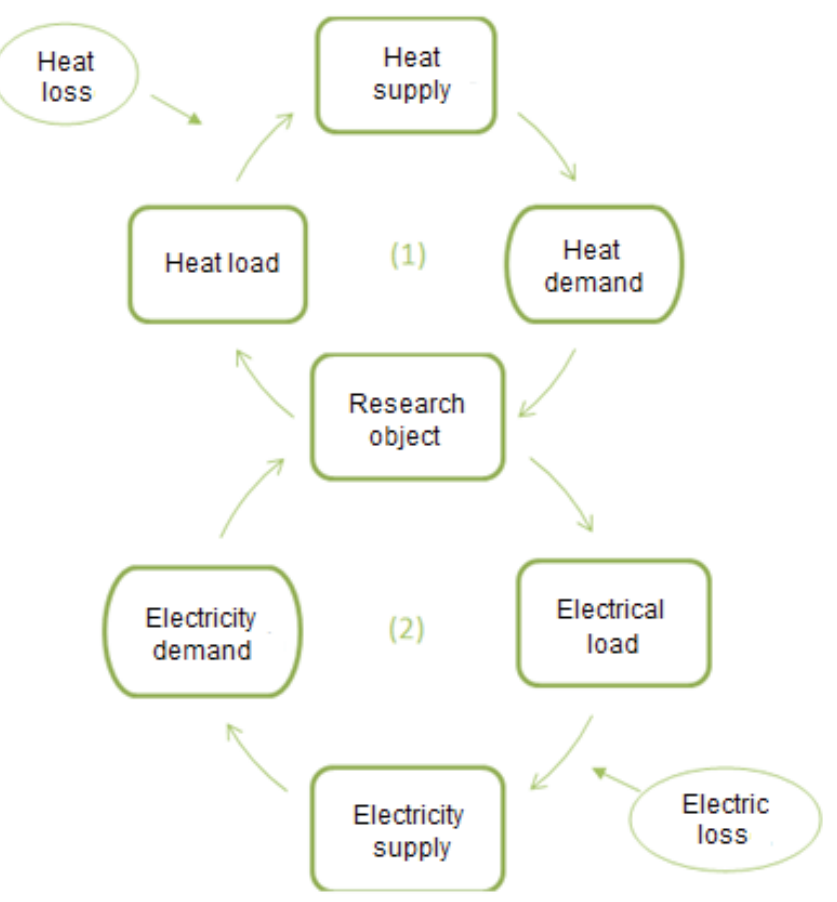

Fig. 6. Merging of causal loops (1) and (2).

The second causal loop: any changes in power supply determine the electricity load assigned to the research object, which in turn determines the operating modes of the research object and the selection of the equipment. The amount of electricity produced by the research object, in turn, affects the overall electricity supply system (see Figs. 6 and 7).

The amount of fuel consumed by the research object depends on the electricity and heat energy produced. Sequentially through Heat load, Electrical load and Fuel consumption sub-blocks, the model algorithm passes from the Research object block to the Savings of primary energy resources block. The Fuel consumption sub-block forms a direct link with the GHGs (Greenhouse gases) sub-block.

\section{Model Prototype Block Savings of Primary Energy Re- sources (5)}

The designed model envisages that savings of primary energy resources affect the demand for primary energy resources (in this case, natural gas) (see Fig. 2). Savings of primary energy 
resources affect the price of natural gas, which in turn influences the operating modes of the research object. Consequently, the third causal loop is being formed (see Fig. 7).

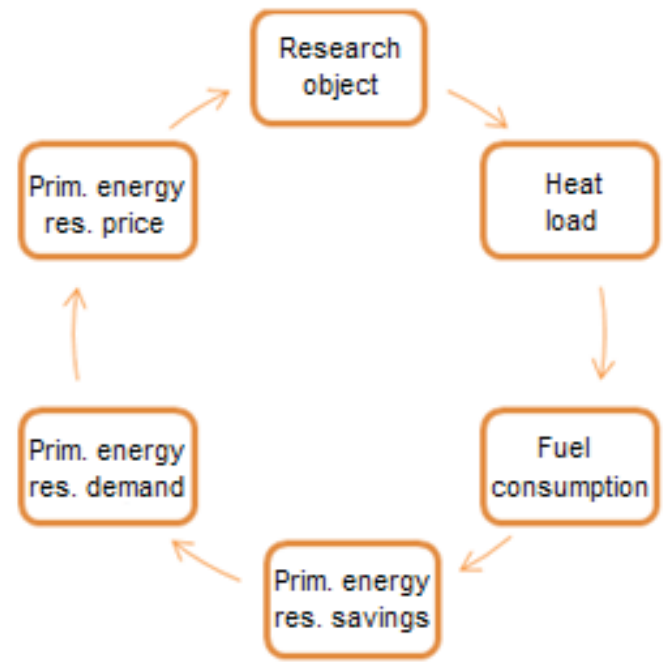

Fig. 7. Causal loop (3).

Savings of primary energy resources also influence the production costs. This, in turn, influences the market price of electricity, and the electricity market price influences the operating modes of the research object. Consequently, the fourth causal loop is being formed (see Fig. 8).

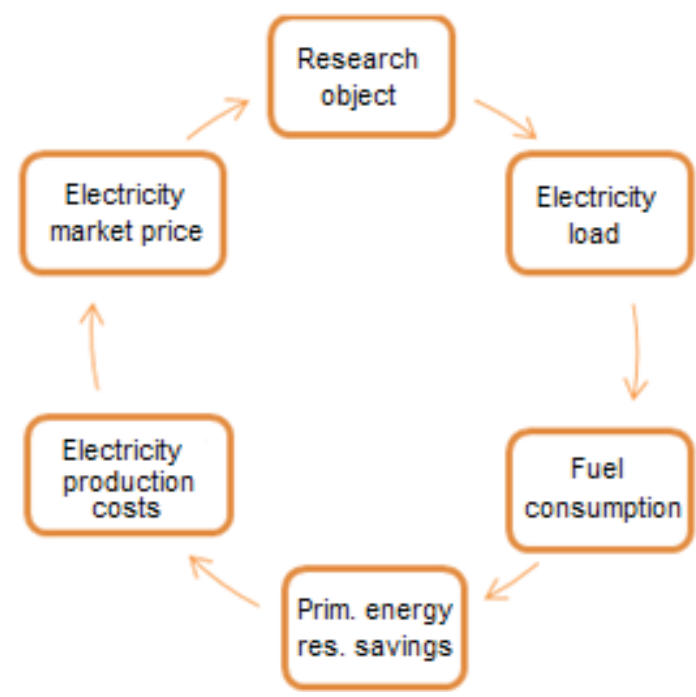

Fig. 8. Causal loop (4).

The designed model envisages the assessment of the total GHGs. Emissions from the Research object, Gas boiler houses and Small CHPs are evaluated in the Total GHGs sub-block. The model also envisages that the price of $\mathrm{CO}_{2}$ allowances set by the RES policy influences the volume of $\mathrm{CO}_{2}$ emissions produced. In other words, a feedback is formed between the $\mathrm{CO} 2$ price and Total GHGs sub-blocks (see Fig. 2).

\section{E. Verification of the Model}

The model algorithm must provide for model verification. The purpose of verification is to give assurance that the model takes into account the main influencing factors and can be used for the practical analysis of situations. Model verification gives answers to the following questions (Blumberga, 2010):

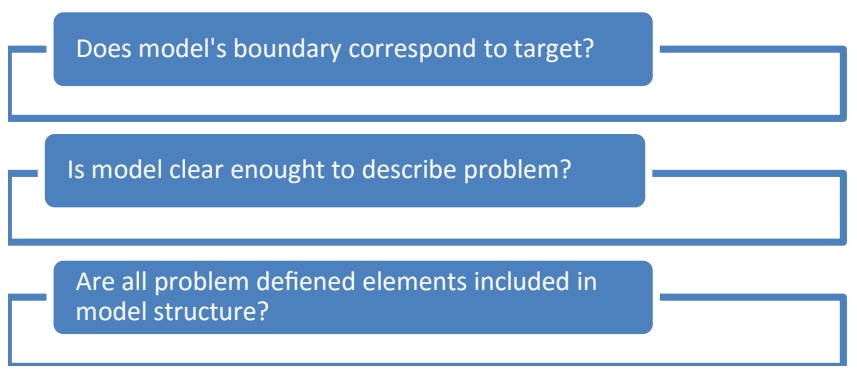

When modelling the object's behaviour, the main task of the system dynamics method is to reflect the actual relationships in the model as accurately as possible (Skribans, 2008). Therefore, the model needs to be verified after the development.

In practice, no model corresponds exactly to the actual object or system being modelled; therefore, no absolutely reliable models exist.

After the verification the model is used for experiments. In other words, the designed models allow for operational change of data in line with the new development trends, and for verification of various hypotheses (Skribans, 2009).

\section{Vi. Implementation of the Designed Model}

Initial calculations with the designed model were made using the Versim computer software. Calculations were made by blocks: Latvenergo CHP block, Market block, Heat block, Consumption block, Small CHPs block, etc. Some of the first model calculation results are shown below.

\section{A. Latvenergo CHP Block}

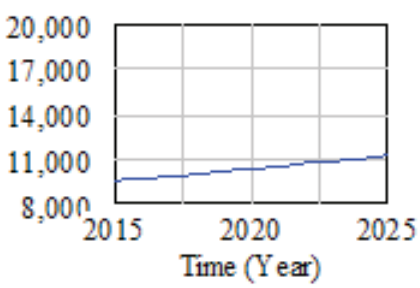

A flat increase in CHP electricity demand is forecast over the coming 10 years (by approximately $10 \%$ ) (see Fig. 9).

Fig. 9. CHP electricity demand.

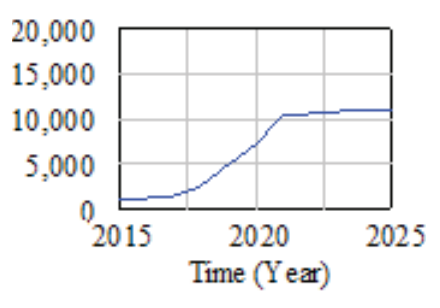

A rapid growth of electricity production is projected until 2021. No significant changes are projected in CHP electricity production volumes after 2021.

Fig. 10. CHP electricity production.

From both Figs. 9 and 10, it can be concluded that such a rapid electricity production by CHPs is associated with the need to fully meet the electricity demand of Latvenergo CHPs. 


\section{B. Market Block}

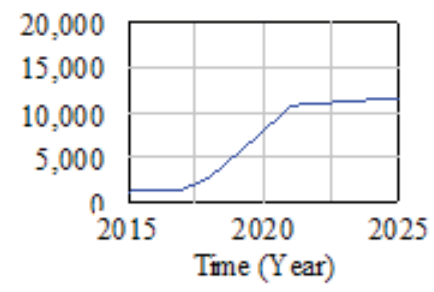

Fig. 11. Total energy produced by CHPs (Latvenergo CHPs + small CHPs).

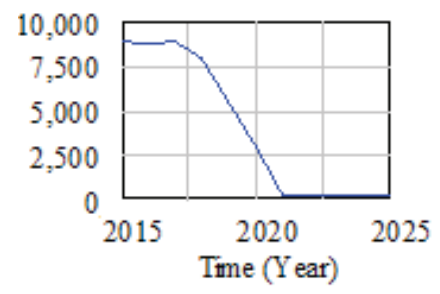

Fig. 12. Electricity import.

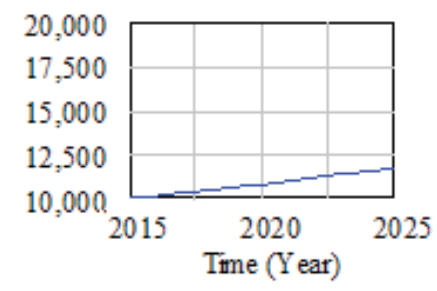

Fig. 13. Market share of electricity consumption (excluding HPPs).

\section{Heat Block}

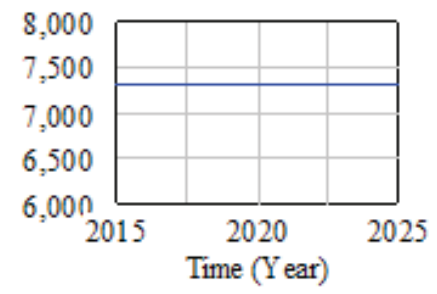

Fig. 14. Heat energy demand by CHPs and boiler-houses.

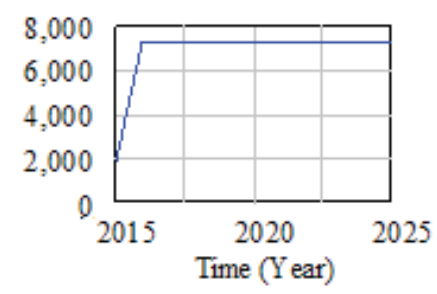

Fig. 15. Heat energy production by CHPs and boiler-houses.

\section{Consumption Block}

In general, a flat total increase of electricity consumption by $11-12 \%$ is forecast (see Fig. 16). At the same time, electricity loss reduction by $20 \%$ is projected (see Fig. 17). A flat electricity con-

and 11 shows that electricity production trends of Latvenergo CHPs and the general CHP production trends are identical.

A rapid decline of electricity import is projected beyond 2017, reaching its minimum after 2021 (see Fig. 12).

A flat increase of electricity market share is projected (see Fig. 13).

No changes in heat energy demand are projected in the future. sumption increase is forecast by sectors (see Figs. 17-20), with the exception of rail transport (Fig. 21) and pipeline transport, where electricity consumption remains unchanged.

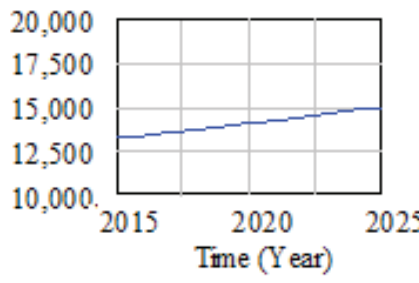

Fig. 16. Total electricity consumption.

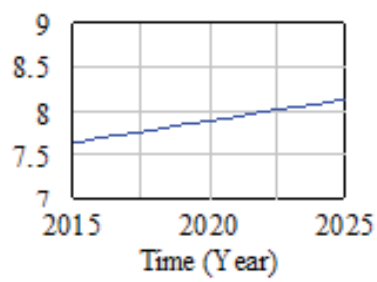

Fig. 18. Electricity consumption by households.

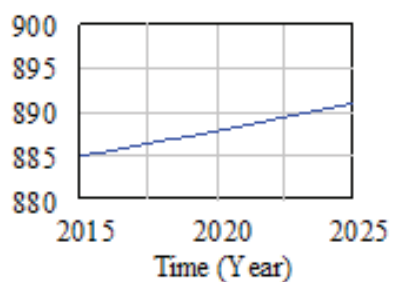

Fig. 20. Electricity consumption in the transport sector.

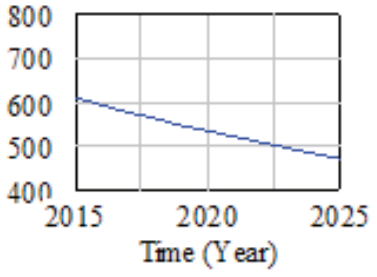

Fig. 17. Electricity loss

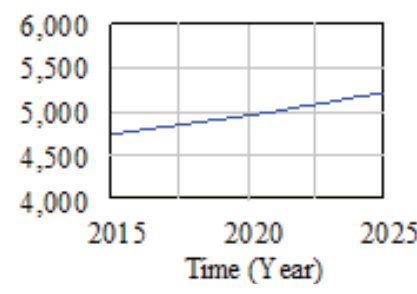

Fig. 19. Electricity consumption in industry.

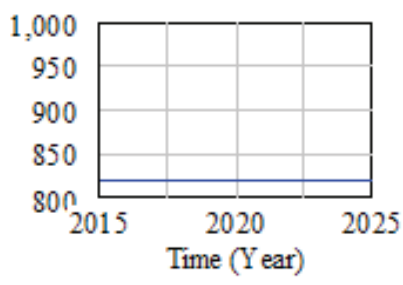

Fig. 21. Electricity consumption in rail transport.

Within the research (Ozolina \& Pocs, 2008), a forecast of electricity consumption until 2019 was made by sectors, and the general trend showed a growth of electricity consumption. Research results of this publication also showed an overall increase in electricity consumption by 2025 .

\section{Situation Analysis}

A situation analysis is based on the evaluation of specific situations (problems). Consequently, the concrete situation being researched and associated with a wider use of RES in energy production must be defined. For example, to increase the use of renewable energy sources on the right bank of Riga District Heating System, construction of a 100 MW biomass boiler-house is planned. The impact of the biomass boiler on Riga thermal power plants is determined through mathematical calculations.

\section{A. Impact of the Biomass Block on the Combined Cycle Blocks}

Construction of a biomass boiler in the right bank heat network of Riga City would reduce the usage and load of the combined cycle (CCGT) energy blocks. This effect would be especially strong during periods of low demand for heat load. This would also be true If the market prices of electricity were lower than electricity production costs in the condensing mode. 
According to the calculations (Kunickis et al., 2014), the construction of biomass boiler would result in decline of heat energy production in CCGT energy blocks by $631 \mathrm{GWh}$, electricity generation by $1.063 \mathrm{GWh}$, and fuel consumption by $2.249 \mathrm{GWh}$. There are two possible options to cover the shortfalls of electricity: to import electricity or produce it in the condensing mode at Riga CHP-2, which, in turn, would promote electricity price increase in NordPool Latvia and Lithuanian price zones.

\section{B. Energy Efficiency Decrease in Riga CSS}

Construction of a new heat source is not preferable in the existing high-efficiency co-generation heat supply area. Construction of a new heat source would reduce possibilities for utilisation of co-generation capacities and, consequently, the energy efficiency of the district heating system.

Production of energy at a co-generation plant is comparable to the production of heat energy in a gas boiler with $90 \%$ efficiency and electricity generation in a combined cycle energy block with a $52 \%$ efficiency rate. After the construction of the biomass boiler energy production at CCGT would be comparable to heat production in a biomass boiler (with an $86 \%$ efficiency rate) and electricity generation in a combustible shale unit (36\%), since these are realistic alternatives in the Baltic energy systems.

Savings of primary energy resources have been calculated for both situations. The results obtained show that energy production at CCGT energy units can ensure $39 \%$ or 1.16 GWh savings of primary energy resources compared to a situation where heat energy is produced in a biomass boiler and electricity in a combustible shale unit.

\section{Increase of $G H G S$}

Use of biomass is GHGs neutral. With the construction of a biomass boiler, emissions resulting from heat energy production would be reduced, and would increase as a result of electricity generation. Since electricity generated in the combined cycle energy units would be replaced by electricity generated at Narva power stations (with 4-5 times higher $\mathrm{CO}_{2}$ specific emissions), the total volume of GHGs would increase.

It is clearly demonstrated by comparing GHGs from electricity generation at Riga CHP-2 and Narva thermal power plants in Estonia (see Fig. 22) (Kunickis et al., 2014).

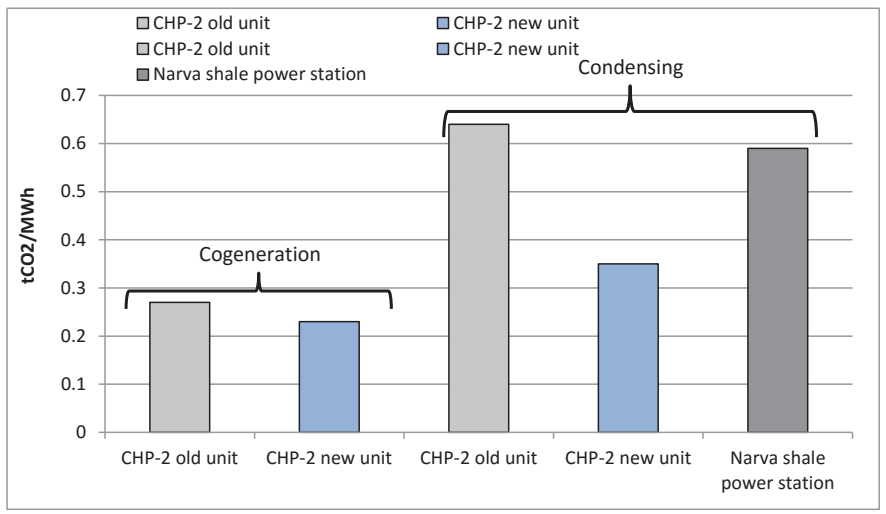

Fig. 22. Comparison of GHGs at Riga CHP-2 and Narva TPP (Kunickis et al., 2014).
It has been estimated that in the event of construction of a biomass boiler the total amount of GHGs might increase by 500 600 tonnes. This is associated with production of additional electricity at Narva plants.

\section{Reduced Security of Electricity Supply}

According to the Transmission System Operator's (TSO) Annual Report 2014, the Latvian energy system is unable to ensure the required security of electricity supply without the combined cycle energy units of Riga CHP-2 (AST, 2015).

A comparison of electrical system power capacity balances was made for the current situation and a situation where the potential new heat source would be constructed and the combined cycle energy units conserved. Under the above scenarios, in 2020 the power capacity deficit would increase from 300 to $1.290 \mathrm{MW}$, while independence would decline from $80 \%$ to $16 \%$, respectively.

\section{E. Impact on Electricity Market Price}

Operational readiness of Riga CHP-2 and the production price of electricity determine the price level of electricity in the Baltics. With the construction of the biomass boiler, a possibility for the combined cycle energy units to operate in an efficient co-generation mode during the summer season (May-September) would be excluded. Operation in the co-generation mode ensures by $40 \%$ lower electricity price compared to the condensing mode. Operating the combined cycle units in the condensing mode would significantly increase the price of electricity in Latvia.

TABLE II

Comparison of Electricity Production Costs When Operating The CCGT in Co-Generation And Condensed Modes (Kunickis et aL., 2014)

\begin{tabular}{|l|c|c|c|c|c|c|}
\hline \multirow{3}{*}{ Month } & $\begin{array}{c}\text { El. } \\
\text { price }\end{array}$ & $\begin{array}{c}\text { Co- } \\
\text { gene- } \\
\text { ration }\end{array}$ & $\begin{array}{c}\text { Con- } \\
\text { densing }\end{array}$ & $\begin{array}{c}\text { Differ- } \\
\text { ence* }\end{array}$ & Amount & Loss \\
\cline { 2 - 7 } & $\begin{array}{c}\boldsymbol{~ M W h ~} \\
\text { MWh }\end{array}$ & $\begin{array}{c}\boldsymbol{\epsilon} / \\
\text { MW/MWh }\end{array}$ & $\mathbf{\epsilon} / \mathbf{M W h}$ & MWh & $\boldsymbol{€}$ \\
\hline January & 42.95 & 43.9 & 67.8 & 24.9 & 77,108 & $1,917,590$ \\
\hline February & 42.73 & 43.3 & 67.0 & 24.2 & 71,739 & $1,739,538$ \\
\hline March & 41.59 & 43.2 & 66.7 & 25.1 & 51,028 & $1,281,670$ \\
\hline April & 44.07 & 43.0 & 66.4 & 22.4 & - & - \\
\hline May & 51.49 & 42.9 & 66.3 & 14.8 & 130,200 & $1,931,774$ \\
\hline June & 54.9 & 43.0 & 66.5 & 11.6 & 126,175 & $1,464,625$ \\
\hline July & 57.34 & 44.0 & 68.0 & 10.7 & 130,200 & $1,392,617$ \\
\hline August & 55.31 & 44.1 & 68.1 & 12.8 & 130,200 & $1,663,989$ \\
\hline September & 58.36 & 44.1 & 68.2 & 9.8 & 125,825 & $1,235,704$ \\
\hline October & 63.7 & 45.1 & 69.7 & 6.0 & 61,360 & 370,876 \\
\hline November & 51.13 & 45.2 & 69.8 & 18.7 & 48,134 & 900,334 \\
\hline December & 43.77 & 45.2 & 69.9 & 26.2 & 111,187 & $2,908,124$ \\
\hline Year & & & & & $1,063,157$ & $16,806,842$ \\
\hline
\end{tabular}

*-difference from the market price.

Table II gives an estimate of the potential losses in the event of a market price increase. The potential electricity cost increase in Latvia is estimated at EUR 17 million (Kunickis et al., 2014). 


\section{CONCLUSION}

Development and utilisation of a system dynamics model in the energy sector requires a complex approach and comprehensive analysis of the situation, as well as attraction of appropriate specialists, experts and scientists, and a broad view of the overall trends not only in the energy sector, but also in the other related sectors.

When designing the model, it is necessary to select all of its key and critical elements (components, blocks, sub-blocks, variables, parameters, etc.), and all the most important relationships of the research object (direct, indirect, feedback, causal, etc.). Inaccuracies may lead to wrong results or incorrect forecasts.

With the help of the designed model, it has been projected that a flat increase in total electricity consumption (ca. 10\%) can be expected in Latvia during the next 10 years and a rapid increase after 2021 (with the exception of some sectors). Decline in electricity loss and electricity imports is projected. Increase of the capacity of the research object and the amount of the produced energy is projected. Further work entails a more detailed evaluation of the model's results in order to consider the need for adjustments.

In contrast to the complex approach, the situation analysis is based on a specific assessment of the situation giving an answer to the question "What happens with... if...?". Thus the situation analysis at the same time provides both the general and narrow perspective of the problem to be addressed.

\section{ACKNOWLEDGMENT}

The paper was supported by the National Research Program 5.2. EKOSOC-LV.

\section{REFERENCES}

AST. (2015). Pārvades sistēmas operatora ikgadējais novērtējuma ziṇojums. Retrieved from http://www.ast.lv/files/ast_files/gadaparskzinoj/ PSOZinojums 2014.pdf

Blumberga, A. (2010). Sistēmiskas domāšanas integrēšana vides politikā. Riga, RTU VASSI.

Herbst, A., Toro, F., Reitze, F., Jochem, E., (2012). Introduction to Energy Systems Modelling. Swiss Journal of Economics and Statistics, 148(2), 111-135.

Hollmann, M., Voss, J., (2005). Modelling of Decentralized energy supply structures with "system dynamics". In: Future Power Systems, 2005 International Conference, 6 p. http://dx.doi.org/10.1109/FPS.2005.204267

Kuṇickis, M., Balodis, M., Sarma, U., Cers, A., Linkevics, L. Efficient use of cogeneration and fuel diversification. Latvian journal and physics and technical sciences, 4 (Vol. 52), 35-36. http://dx.doi.org/10.1515/LPTS-2015-0034

Ozolina, V., Pocs, R. (2013). Macroeconomic Modelling and Elaboration of the Macro-Econometric Model for the Latvian Economy (Scientific monograph). Riga, RTU Press.

Pocs, R., Ozolina, V. Electricity Consumption Dynamics and Forecasts in Latvia. In: Structural Changes, International Trade and Multisectoral Modelling: the 15th INFORUM World Conference, 239-260.

Skribans, V. (2008). Modelling of the new product introduction into market, using system dynamics method. Economic and Business. 17, 99-105.

Skribans V. (2010). Development of the Latvian energy sector system dynamic model. Scientific Journal of Riga Technical University - Power and Electrical Engineering, 26, 33-39.

Skribans, V. (2009). Influence of the Crisis and 2009 Tax Policy Changes on the Latvian Economy. Latvijas Universitātes raksti: Ekonomika. Vadības zinātne, 743, 189-200.

Skribans, V. (2009). Taxes Income Modeling with System Dynamic Method In: 50. RTU Starptautiskā zinātniskā konference: RTU IEVF Ekonomikas un uzn̄èmējdarbübas zinātniskā konference (SCEE' 2009): konferences rakstu krājums, 474-481.
Skribans, V., Pocs, R. (2012). Analysis of Latvian Integration Processes in EU Using System Dynamics Model. The 7th International Scientific Conference “Business and Management 2012”: Selected Papers, 494-504. http://dx.doi. org/10.3846/bm.2012.065

Zīgurs, Ā., Kunickis, M., Linkevics, O., Stuklis, I., Ivanova, P., Balodis, M. (2015). Evaluation of Exhaust Gas Condensing Economizer Installation at Riga CHP Plants. In: Proceedings of REHVA Annual Conference 2015, 149-154. http://dx.doi.org/10.7250/rehvaconf.2015.021

Forrester, J. (1958). Industrial Dynamics - A Major Breakthrough for Decision Makers. Harvard Business Review, 36(4), 37-66.

Kavrakoglu, I. (1980). Decision analysis in the energy sector. Applied Mathematical Modelling, 456-462. http://dx.doi.org/10.1016/0307-904X(80)90178-X

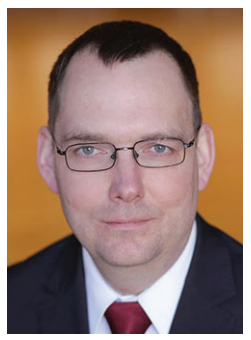

Māris Balodis was born on 4 July 1970 in Dobele, Latvia. He received Dipl. Ing. in Electrical Engineering and Master's degree in Economics from Riga Technical University in 1993 and 1995, respectively. After graduation from Riga Technical University in 1993, Maris. Balodis started his career at Latvian national power utility State Latvenergo JSC. He has 21 years of working experience at the company in various positions. Currently, he holds the position of the Director of Research \& Development. His main competence is preparation of development programmes and strategies, research and feasibility studies.

Maris Balodis is a member of working groups of the European Union of the Electricity Industry EURELECTRIC, and of the European Technical Association VGB PowerTech e.V.

Mob.: +37129436627.

E-mail: maris.balodis@latvenergo.lv

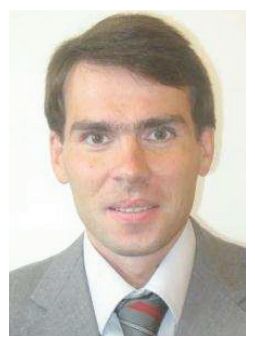

Valērijs Skribans, Dr. oec., 2006, Riga Technical University. He is a Leading Researcher, Assistant Professor of Riga Technical University; he has experience of managing chair; more than ten years of practical work in Economist and Financial Officer positions. He is a specialist in system dynamics. He is a member of the International System Dynamics Society, Society for the Study of Emerging Markets, Archive of the Munich Personal Research Papers in Economics, Russian System Dynamics Society, Imitation and Modelling Society (Latvia), Latvian Association of Econometrics.

Address: Kalnciema Str. 6, Room 107, Riga, LV1048, Latvia.

Mob.: +37126429535

E-mail: valerijs.skribans@rtu.lv

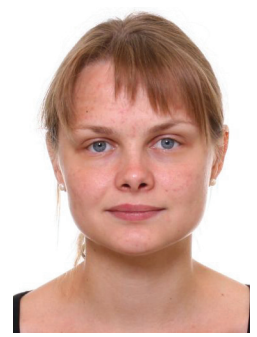

Polina Ivanova was born in 1989. She received Bachelor degree in Environmental Science in 2012 from Riga Technical University, the Faculty of Electrical and Power Engineering. She received Master degree in Heat Power and Heat Engineering from Riga Technical University, the Faculty of Transport and Mechanical Engineering (2015). She underwent practical training at Balteneko Ltd. and Latvenergo JSC. She has working experience as a Planning Engineer at Latvenergo JSC. She is also a member of working groups for the VGB PowerTech e.V Technical Association.

Mob.: +37129910809.

E-mail: polina.ivanova@latvenergo.lv 